\title{
Probable ATP-Dependent RNA Helicase DDX41
}

National Cancer Institute

\section{Source}

National Cancer Institute. Probable AT P-Dependent RNA Helicase DDX41. NCI

Thesaurus. Code C151915.

Probable ATP-dependent RNA helicase DDX41 (622 aa, 70 kDa) is encoded by the human DDX41 gene. This protein may play a role in gene splicing. 